\title{
PERANAN DAN SIKAP TRANSFORMASI POLITIK ULAMA DALAM MENGHADAPI PEMILU 2014 DI ACEH
}

\author{
Ridwan Hasan \\ STAIN Malikussaleh Lhokseumawe-Aceh \\ Email: ridwanmth@yahoo.com
}

\section{Abstract}

Cleric is a person who always used various references in Acebnese society especially in politics toddy. Even now, most local political parties participated also pioneered by some scholars communities in Aceh. The rale and attitude of the clergy in the face of the year 2014 election greatly affect the performance of legislative policy on the future, because the legislature is as representative of the general public. With the implementation of Qanun in Nanggroe Aceh Darussalum (NAD) policy concerning both national parties (Parnas) and local political parties (Parlok) has contributed and a more mature understanding of politics, because the phenomenon will occur in the 2014 election abead is a form of democracy the general public. Surely democracy must apply the principle of the system or if only to push forvard or succeed to be submitted a candidate, is one of the 2014 elections itself. So that all policies of public interest can be accepted and applied in different elements of the community through the election to be beld.

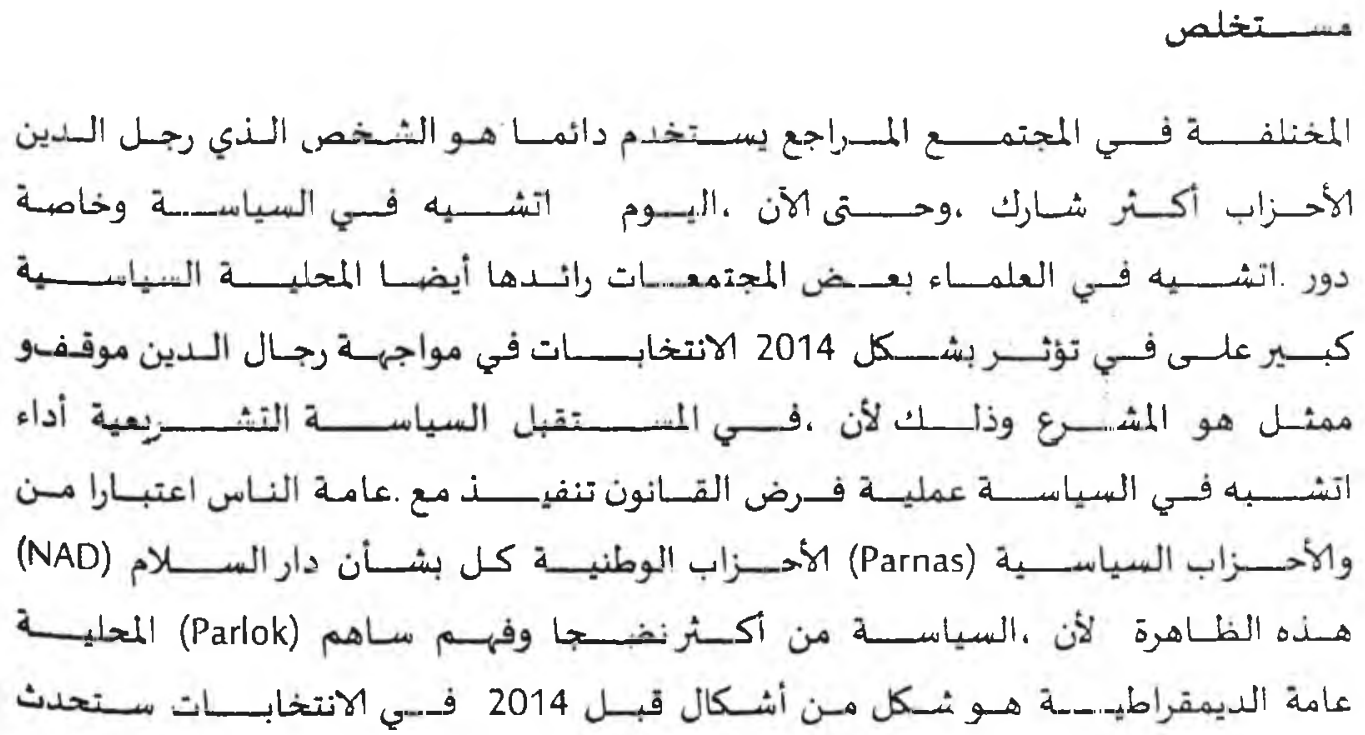




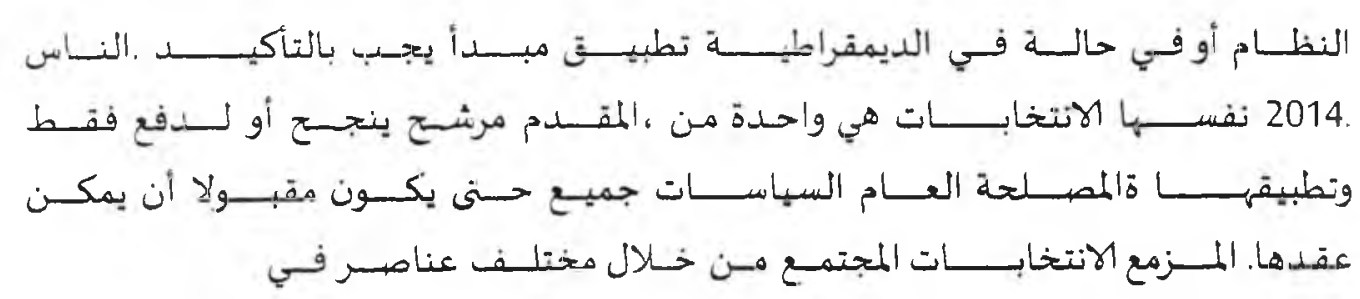

\section{A. Pendahuluan}

Kata ulama' berasal dari akar kata bahasa Arab, alima-ya'lamu-ilman; maksudnya mengetahui/pengetahuan; lawan dari kebodohan (dbiddu al-jabl). Isim fa'ilnya 'alim dan bentuk jamaknya 'alimun, ullam atau 'ulama'; maknanya adalah orang yang berilmu; lawan dari orang yang bodoh atau yang tidak berpengetahuan (dhiddu al-jabi). Jika pengetahuannya luas sekali dikataka 'allamah, maknanya sangat ahli/sangat berpengetahuan, sementara dalam bentuk superlatifnya 'alimun.

Namun, beberapa hadist, telah deskripsinya lebih menjelaskan bahwa ulama $^{2}$ yang dikehendaki oleh Islam. Dari sinilah para ulama, ketika menyebutkan kata ulama tanpa disertai adjektif (sifat), menyatakan bahwa yang

1 Ulama, berasal dari bahasa Arab, jamã' daripada kata 'alim yang, orang yang merigetahui, adalah kumpulan umat yang mendalami ilmu-ilmu agama, juga dijadikan tempat umat untuk meminta fatwã. Pengakuan ini diberikan Allah kepada mereka dengan melebihkannya beberapa darjat. Lihat, Sürat, al-Mujäd Allabal. 11. Di daerah Aceh ada dua pembahagian ulama; Pertama, ulama tradisional ia, ulama yang selalu berpikir dan berpegang teguh pada kitab Allah dan menguasai secara baik hukum syara', juga memiliki sifat tawẩdbu' dan istigāmah kepada Allah, dan disebut juga ulama Dayah (pondok), kampung atau ulama ahkirat. Kedwa, ulama modern yang mampu tampil didepan sebagai Imãm dan rakyat sebagai maknümnya. Di samping memiliki kedalaman ilmu agama dengan asas ahklak yang tinggi, juga mereka dapat menerima perubahan yang terjadi sebagai dampak kemajuan ilmu pengetahuan dan teknologi. Lihat, Badruddin Subqi. Dilema Ulama Dalam Perubaban Zaman, Jakarta: Gema Insan: Press, 1995), hal. 56. Lihat juga, Fairus M. Nur Ibrahim (ed), Syari'at di Wilayah Syari'at: Pernik-Pernik Islam di Nanggroe Aceb Darussalam.Banda Aceb: Dinas Syari'at Islam, 2002), hal. 247.

2 Imam ad-Darimi, menukil dari Sufyan ats-Tsauri, menyatakan bahwa ulama itu ada tiga macam: Periama, orang yang alim (mengetahui) tentang Allah dan ia takut kapada Allah, tetapi ia tidak mengetahui perintah (ketentuan) Allahal. Kedua, orang yan mengetahui Allah, juga mengetahui perintah (ketentuan) Allah, dan ia takut kepada Allahal. Ia adalah seorang alim yang sempurna. Ketiga, otang yang mengetahui perintah (ketentuan) Allah, tetapi tidak mengetahui Allah dan ia tidak takut kepada Allah, dialah seorang alim yang fajir (ulamo as-su). 
dimaksud adalah ulama yang dikehendaki Islam ini. Adapun jika yang dikehendaki adalah ulama dari jenis yang lain biasanya disertai dengan adjektif, seperti ungkapan: ulama as-su' (ulama yang buruk), ulama as-salathin (ulama penguasa), ulama al-fajir (ulama yang jahat), dan sebagainya.

Apabila dilihat dalam sejarah bahwa Nanggroe Aceh Darussalam $(\mathrm{NAD})^{3}$ yang banyak mengambil peranan dalam memperjuangkan aspirasi masyarakat pada masa itu adalah sebagai peranan ulama dengan sikap yang bijak dalam mengsikapi kebijakan sosio-politik pada saat itu. Sementara, sekarang ini tclah terbentuk satu lembaga yang diberi nama dengan $\mathrm{MPU}^{4}$ yang anggotanya terdiri atas ulama dan cendikiawan muslim yang memahami ilmu agama Islam dengan memperhatikan keterwakilan perempuan, akan tetapi lembaga tersebut telah diatur dalam Qanun bahwa ulama yang terlibat dalam wadah. MPU tidak dibenarkan untuk terjun dalam dunia politik praktis, sehingga dapat memberikan nilai negatif padanya, sehingga masyarakat kurang simpati padanya.

Ibnu Taimiyah dalam bukunya Siyasah al-Syarizyah dalam etika politik Islam, menekankan bahwa kriteria yang harus dipenuhi dalam memilih seorang pemimpin untuk memegang jabatan ketua dalam suatu negara adalah harus memastikan mereka memiliki dua sifat penting iaitu kemampuan dalam mengurusi negara, amanab dan tanggungjawab terhadap yang dipimpinnya. Beliau juga turut memberikan suatu kekuatan dari aspek pemerintahan itu berdasarkan pada pengetahuan menjalankan keadilan sebagaimana menurut al-

3 Undang-undang Nanggroe Acch Darussalam (NAD), disahkan dan disetujui olch Dewan Perwakilan Rakyat Republik Indonesia (DPR-RD) carikh 19 Juli 2001, sebagai undangundang Otonomi Khusus Provinsi Daerah Istimewa Acehal. Sebelumnya lebih dikenal dengan sebutan Daerah Istimewa Aceh (D.I. Aceh), karena berdasarkan dengan Keputusan Perdana Menteri Republik Indonesia, Nomor. 1/ Missi/ 1959 terhitung mulai tanggal 26 Mej 1959, ditetapkan bahwa Daerah Swatentera Tingkat I Aceh dapat juga disebut, Daerah Istimewa Acehal. Keputusan ini, disempurnakan lagi dengan Penetapan Presiden No.6 rahun 1960, dan terakhir disesuaikan pula dengan undang-undang No.18 tahun 1965, maka secara resmi Daerah Istimewa Aceh disebut, Provinsi Daerah Istimewa Acehal. Lihat, Monografi Daerab Istimewa Aceh, (Banda Aceh: Universitas Syiah Kuala Darussalam, 1972), hal. 29.

4 Dalam Peraturan Daerah, No. 3 tahun 2000 tentang, Pembenukan Organisasi dan Tata Kerja Majlis Permusyawaratan Ulama (MPU) Provinsi Daerah Istimewa Aceh pada tanggal, 14 Juni 2000 (lembaga daerah No. 23 tgl, 22 Juni 2000). Lihat, Rusdi Sufi, (peny). Adat Istiadat Masyarakat Aceh, hal. 37. Lihat juga, Ismuha. Sejarah Singkat Ulana Provinsi Daerab Istimewa Aceh, (Banda Aceh: Sekretariat MUI Provinsi D.I. Aceh, 1983), hal. 1. 
Qur'an dan sunnah dan kemampuan melaksanakan hukuman yang harus dijalankan tanpa ada suatu rasa kekwatiran terhadap manusia. Sementara secara umum, latarbelakang ulama yang tinggal di daerah Nanggroe Aceh Darussalam digolongkan ada dua kelompok: 1. Ulama yang mempunyai latarbelakang pendidikan agama yang didapati dari institusi pesantren sebagai lembaga non formal. 2. Ulama yang pempunyai latarbelakang pendidikan agama yang didapati dari institusi formal. ${ }^{5}$

Dalam kalangan masyarakat di daerah Aceh umumnya, bahwa ulama sclalu dijadikan suatu tempat referensi dari perbagai masalah yang menyangkut dengan permasalahan hukum dan politik baik yang berhubungan dengan Tuhan, individu ataupun dengan masyarakat kesehariannya, sehingga daetah tersebut juga dikenal dengan sebutan Serambi Mekah. ${ }^{6}$ masyarakat Aceh terdapat satu filsafah yang hingga sekaraang ini, masih juga dijadikan sebagai pedoman dasar dalam kehidupan sehariannya:

\section{Adat bak. Poteu Meureubom \\ Hukom bak Syiah Kuala, \\ Kanun bak Putme Phang, \\ Reusam bak. Bentar}

Artinya:
Adat dipimpin oleh Seribaginda Raja.
Hukum dikendalikan oleh Pejabat Kerajaan,
Kanun ditangan Puteri Pahang,
Resam diatur oleh Bentara.

Maksud dari filsafah di atas untuk menyatakan bahwa, kehidupan masyarakat $\Lambda$ ceh sejak masa lalu telah bersendi dan berpegang erat kepada hukum, adat dan resam. Hukum adat juga memainkan peranan penting dalam

5 Bahan-bahan Seminar, Sejarab Masuk dan Berkembangnya Islam di NAD, (Banda Aceh: Majlis Ulama Indonesia (MUI-NAD), 1978), hal. 9.

6 Daerah Istimewa Aceh, Buku Profil Pravinsi Republik Indonesia, Jakarta: Yayasan Bhakti Wawasan

Nusantara, 1992), hal. 297.

7 T. Alibasya Taisya, Adat Resam Aceh, (Banda Aceh: Pustaka Mutia, 1985), hal. 5. 
pembentukan watak, pola fikiran dalam perubahan struktur sosial dalam masyarakat Aceh, khususnya dalam dunia politik.

Dalam penelitian yang akan dijalankan harus mendapatkan dan memberiakan hasil daripada penelitian tersebut, untuk memperoleh hasil yang diharapkan maka diperlukan kajian yang mendalam mengenai bagaimana sikap dan kebijakan para ulama dalam menghadapi pemilu 2014, dan mengungkapkan lebih dalam keterlibatan peranan dan sikap para ulama untuk mentraspormasi nilai sosial dalam berpolitik, serta bagaimana tingkat efektifitas proses untuk mensukseskan pemilu 2014.

Dalam penelitian peranan dan sikap politik ulama dalam menghadapi pemilu 2014, yang telah diulas oleh para ulama dan cendekiawan Aceh terdahulu. Namun, kebanyakan kajian yang telah dilakukan adalah bercorak penghuraian deskripsi dalam politik saja. Maka hingga kini, belum ada terdapat penelitian tentang peranan dan sikap sosio-politik ulama yang berdomilisili di Nanggroe Aceh Darussalam (NAD). Adapun yang dapat dihubungkan dengan tinjauan kepustakaan dalam kajian ini yang telah dijalankan oleh pengkaji.

Maka pesta demokrasi dalam dunia politik bagi ulama Aceh Utara adalah merupakan suatu masalah yang sangat menarik untuk dijadikan sebuah kajian bahkan sebagian ulama juga ikut terlibat didalamnya. Namun, yang dapat dihubungkan dengan tinjauan pustaka dalam penelitian yang telah dikaji pada masa yang lalu. Sementara masalah peranan ulama dan sikap yang telah terlibat didalamnya para pengkaji dalam dan luar negara dari beberapa kajian yang telah dilakukan oleh para pengkaji.

\section{B. Profil Ulama Daerah Aceh}

Prinsipnya ulama merupakan sebagai panutan dan rujukan berbagai hukum dan permasalahan yang terdapat dalam masyarakat Aceh pada umumnya, sehingga sebagian orang membagikan terdapat ada dua corak ulama diantaranya seperti:

\section{Ulama Aktif Dalam Partai tertentu}

Tidak mengherankan apabila kalangan kritis generasi muda muslim, menyebutkan bahwa ulama berpolitik memilih dua jalan "ideologis". Jalan 
pertama adalah jalan surga, apabila ulama yang berpolitik benar-benar memegang teguh amal-ajaran Islam (ajaran agama) dan mempraktekan sebagai filosofi nilai untuk mendorong partai menjadi kekuatan yang membela kepentingan publik. Jalan kedua, adalah jalan "kegelapan politik" apabila ulama berpolitik justru tidak membawa perubahan partai menjadi kekuatan pembela kepentingan publik. Justru teribat dalam aktifitas "dosa sosial" seperti membiarkan praktek korupsi dan permisif terhadap kebijakan sosio-politik kekuasaan yang anti kepentingan objektif masyarakat miskin (mustadb'afin). Ali Syariati ideologi Revolusi Islam Irar memberikan "petuah" sosial, apabila ulama terjun ke dalam politik praktis, yakni:

Pertama, ulama harus benar-benar menjaga nilai-nilai keadilan, kesucian dan keberpihakan kepada kepentingan ummat (rakyat jelata/mustadb'afin). Tidak menjadi bagian dari kekuasaan yang menindas (despostik).

Kedua, ulama yang berpolitik harus meninggalkan praktek kemunkaran pribadi/kolektif yang menempatkan agama sebagai legitimator tindakan politik. yang anti kepentingan kaum (mustadh'fin). Para ulama harus menghindari menjadi "kelompok elit" yang memanipulasi kebenaran sosial menjadi kebenaran elit kekuasaan.

Ketiga, ulama yang berpolitik adalah menegakkan syariah agama menjadi media pembebasan nasib kaum papa dan menjadi "hukum moral" yang menghentikan praktik ketidakadilan ekonomi-politik. Ulama yang berpolitik harus teguh dalam memegang prinsip dan integritas moral karena menjadi panutan ummat (masyarakat). Memang panggung kepartaian di Indonesia memerlukan kehadiran ulama. Ulama yang berpolitik bukan didasari motivasi meraih kedudukan atau alasan "ideologis" yang absurd. Panggung perpolitikan nasional memerlukan ulama yang merakyat, bukannya ulama yang "rajin" mengeluarkan fatwa tanpa toleransi. Fatwa yang menisbikan nasib ketidakadilan rakyat jelata. Ulama yang berpolitik yang membawa kemaslahatan sosial adalah yang membawa nilai-nilai pembauran yang benar-benar memanusiakan manusia. Dan menegakkan prinsip kebenaran moral agama di atas kepentingan eksklusif kekuasaan. 
Kemunduran umat Islam saat ini, di antaranya disebabkan tidak memiliki kader atau figur politisi yang konsekuen yang dapat membawa visi dan misi Islam. Musuh-musuh Islam dari Eropa (barat) setiap saat melakukan "pencucian otak" bagi umat Islam melalui berbagai media dan universitas yang "berkiblat" kepada barat. Mereka mengembangkan panam sekularisasi dalam bidang politik, kader-kader Islam yang mampu berpolitik untuk kepentingan Islam tidak boleh terlibat dalam kancah politik praktis.

Al-Ghazali misalnya berpendapat, agama dan politik, dunia dan akhirat berkait erat. Karena menurutnya tujuan manusia dalam bermasyarakat bukan untuk memenuhi kebutuhan dan mencari kebahagiaan materil semata, melainkan mempersiapkan kehidupan yang lebih sejahtera dan abadi di akhirat. Dunia untuk agama dan agama untuk mengatur dunia. Al Ghazali merumuskan bahwa agama adalah fundamen (asblu) dan kekuatan politik adalah penjaganya. Untuk menjaga agama dari kehancuran maka dubutuhkan suatu kekuatan politik, kekuatan politik takkan mampu menjaga agama kalau tidak diisi oleh orang-orang yang memahami agama.

Antara politik dengan ulama tidak dapat dipisahkan dalam sebuah kehidupan berbangsa dan bernegara. Sejarah sosial politik bangsa Indonesia membuktikan bahwa kalangan ulama senantiasa terlibat aktif dalam dinamika berbangsa dan bemegara. Memang yang terjadi selama ini adalah "ulama politik" yang bermakna bahwa ulama mengikuti kehendak partai politik dan para politisi. Akibatnya ulama kerapkali terlilit stigma politik praktis yang bercorak negatif dan pada akhimya mengurangi, bahkan dapat memberikan dampak sehingga menghancurkan kredibilitas lembaga ulama bahkan pribadi sekalipun. Konon, ulama kalau sudah terjun ke dunia politik sama halnya dengan para politisi lainnya sehingga meninggalkan tujuan yang sebenarnya. Ini adalah karakter "ulama politik (ulama yang ikut arus politik)" yang harus didekonstruksi.

Namun, yang harus dibangun adalah "politik ulama". Maksudnya, pertama, partai politik atau politisi harus mengikuti bimbingan dan arahan para ulama yang diakui secara luas di masyarakat integritas moral dan keilmuannya, serta dikenal terbebaskan dari belenggu kepentingan politik. Kedua, karakter 
keulamaannya tetap bersikap aktif dalam meretas berbagai bentuk penyimpangan politik. Ketiga, menanamkan nilai-nilai keulamaan dalam diri. Jadi, ulama bukan hanya sebagai simbol tapi nilai-nilai keulamaannya yang tertanam sehingga menjadi benteng terhadap berbagai bentuk penyimpangan politik.

Sebelum berbicara lebih jauh tentang hal tersebut penting dipahami apa yang disebut politik. Memang, politik dapat didefinisikan dengan berbagai cara. Tetapi, bagaimanapun dapat didefinisikan, satu hal sudah pasti, bahwa politik menyangkut kekuasaan dan cara penggunaan kekuasaan. Dalam pengertian sehari-hari, politik juga berhubungan dengan cara dan proses pengelolaan pemerintahan suatu Negara. ${ }^{8}$

Dalam kontek sistem sekuler, bahwa dunia politik lebih didasarkan pada politik Machiavellis yang ditullis dalam buku The Prince. Machiavellis mengajarkan bahwa: (1) kekerasan (violence), brutalitas, dan kekejaman merupakan cara yang diperlukan penguasa; (2) penaklukan total atas musuhmusuh politik dinilai sebagai kebajikan puncak; (3) dalam menjalankan kehidupan politik seseorang harus dapat bermain seperti binatang buas. Karenanya, praktik politik sistem sekuler merupakan homo homini lupus, manusia menjadi serigala terhadap manusia yang lain. Slogannya pun kiranya dapat diterima akal bila demi tuntutan profesionalnya. seorang serdadu harus membunuh dan seorang politikus harus menipu (It is thought that by the necessities of his profession a soldier must kill and politici on lie). Fakta memberikan satu gambaran bahwa politik seperti inilah yang menjadikan sebagian kalangan Muslim tertipu dan terpedaya hingga menyimpulkan bahwa dunia politik itr kotor. Karenanya, Islam tidak boleh mencampuri politik, Islam harus dipisahkan dari politik. Sebagai contoh bahwa dakwah Nabi pun diposisikan sebagai dakwah spiritualitas dan moral belaka dan bukan dakwah bersifat politik.

Politik dalam bahasa Arab dikenal dengan istilah siyasab, artinya mengurusi urusan, melarang, memerintah (Kamus al-Muhith, dalam kata kunci

8 Amien Rais, Cakrawala Islam Antara Cita dan Fakta, (Jakarta: Mizan Pustaka, 1987), hal. 27. 
sasa). Nabi menggunakan istilah politik (siyasab). Jadi, politik artinya adalah mengurusi urusan umat. Berkecimpung dalam dunia politik berarti memperhatikan kondisi kaum Miuslim dengan cara menghilangkan kezhaliman penguasa dan melenyapkan kejahatan kaum kafir atas mereka. Politik Islam karenanya berarti mengurusi urusan masyarakat melalui kekuasaan melarang dan memerintah dengan landasan hukum/syariat Islam. Bila dilihat dari hubungan antara makna ulama dengan makna politik maka semestinya ulama dan politik Islam tidak dapat serta tidak boleh dipisahkan antara satu dengan yang lain, artinya ulama harus mengurusi urusan umat atas dasar Islam.

\section{Sebagai Pimpinan Partai Politik}

Islam berbeda dengan itu. Politik dalam bahasa Arab dikenal dengan istilah siyasah, artinya mengurusi urusan, melarang, memerintah (Kamus alMuhith, dalam kata kunci sasa). Nabi menggunakan istilah politik (siyasah). Jadi, politik artinya adalah mengurusi urusan umat. Berkecimpung dalam dunia politik berarti memperhatikan kondisi kaum Muslim dengan cara menghilangkan kezhaliman penguasa dan melenyapkan kejahatan kaum kafir atas mereka. Politik Islam karenanya berarti mengurusi urusan masyarakat melalui kekuasaan melarang dan memerintah dengan landasan hukum/syariat Islam.

Keinginan Ulama Aceh saat ini untuk kembali tampil dalam kancah politik dengan menyatukan ulama-ulama Dayah adalah upaya untuk mewarnai politik dan parlemen Aceh dari berbagai kalangan yang nantinya diharapkan mampu menampung aspirasi semua lapisan masyarakat. Para Tengku dari Dayah dapat menjadi satu kekuatan umat yang sangat determinan, diharapkan peran strategisnya dalam berbagai bidang, baik sosial, politik, ekonomi dan budaya yang memberikan perubahan kepada umatnya. Dalam membina dan memimpin umat, juga sebagai "obat penyembuh" dari segala penyakit pemerintah dan rakyat. Dan sebenarnya, keterlibatan dan intervensi ulama dayah Aceh dalam politik, baik secara langsung maupun tidak langsung bukan akan menciptakan perpecahan umat jika semua dilakukan dengan ikhlas."

9 Amirullah Muhammadiyahal. Ulama dan Politik. (Tesis), hal. 43. 


\section{Peranan Ulama Dalam Menghadapi Pemilu 2014}

Dalam masyarakat Aceh ulama merupakan salah seorang selalu dijadikan sebagai profil yang menjadi panutan dalam kebanyakan masyarakat baik itu menyangkut kebijakan sosial, agama maupun politik. Apabila dilihat dalam sejarah bahwa ulama masa dahulu bukan saja berkecimpung dalam bidang agama saja akan tetapi hingga dalam ranah politik yang di kuasainya salah seorang ulama yang berkaliber nasional seperti HAMKA.

Salah satu contoh bahwa ketika hampir mendekati detik-detik pelaksanaan Pemilu, sebagian besar dikalangan ulama di Provinsi Nanggroe Acen Darussalam (NAD) serta untuk mengimbau kepada seluruh masyarakat untuk segera menghentikan segala bentuk teror dan intimidasi, sehubungan dengan situasi politik yang mulai memanas menjelang pelaksaan Pemilu 2009. Seperti mengatakan pelemparan bahan peledak dan pencabutan atribut partai politik tertentu yang dilakukan orang tidak bertanggungjawab harus segera dihentikan oleh aparat kepolisian (Polri) setempat.

Ia juga mengimbau partai politik dan caleg peserta Pemilu untuk menyampaikan visi dan misi dengan cara mendidik masyarakat pemilih agar mereka cerdas dalam berpolitik, bukan teror dan intimidasi. Lebih jauh ia mengatakan, pemerintah Aceh dan legislatif diimbau agar menggalang kekuatan untuk merealisasikan pelaksanaan Pemilu damai di provinsi ujung paling barat Indonesia ini. "Saatnya seluruh elemen masyarakat bekerja untuk membangun Aceh yang aman, damai dan sejahtera menuju daerah yang bersyariat dibawah bingkai Negara Kesatuan Republik Indonesia (NKRI).

Dijelaskan, teror dan intimidasi bukan sebuah "budaya" dalam Islam dan masyarakat Aceh. "Kalau partai politik atau caleg ingin meraih suara terbanyak daiam Pemilu maka lakukanlah dengan santun, tanpa mengintimidasi atau pemaksaan terhadap warga,"

Ulama (kiai) kemudian dikatakan sebagai "shadow of the ummab", bayangbayang umat. Ulama yang pandai berorasi dan akrab di telinga umat merefleksikan kegandrungan publik akan wacana. Ulama yang cenderung 
bermain padat tataran superfisial, dengan demikian, juga setali tiga uang dengan religiositas umat yang eksis hanya di lapis luarnya.

Pada masa lalu, sempat terjadi "krisis kepercayaan" umat (masyarakat) terhadap ulama akibat 'kedekatan' dan kuatnya cengkeraman penguasa (umara). Para ulama (kiai) atau pemuka agama kala itu dianggap sebagai "tukang stempel" yang melulu hanya memberikan pengabsahan atau "pembenaran" atas kebijakan pemerintah (negara). Namun kini yang dicemaskan adalah bagaimana para ulama (kiai) atau pemuka agama itu telah terkooptasi oleh jejaring kapitalisme. Dibalik bermunculannya ulama generasi baru ini, ada sebagian kalangan yang boleh jadi tidak melihat ulama itu sebagai aktor yang memainkan nilai-nilai religiositas.

Ulama atau pemuka agama itu cenderung kurang memahami sofistikasi proses politik, yang kadang-adang tidak bisa mereka (ulama) pahami. Sebab sebenarnya kepedulian ulama itu bukan pada tataran politik (praktis), namun bagaimana menegakkan syariat dan bagaimana membentuk generasi muslim yang berakhlak dan berkepribadian mulia. Ulama tidak boleh terkonsentrasi pada satu kekuatan politik tertentu, sehingga tidak terkotak-kotak. Karena itulah fenomena ulama kehilangan pengaruhnya secara signifikan dalam proses politik dan pemilihan umum bisa dimaklumi.

\section{Sistem Pelaksanaan Pemilu di Aceh}

Pemilihan umum yang di laksanakan di NAD selama ini lebih dikenal dengan electoral thresbold (ET). ${ }^{10}$ Sistem pada kebiasaan digunakan sebagai batas perolehan suara partai-partai politik untuk mendapatkan suara yang lebih banyak dan maksimal sebagaimana yang diharapkan dalam Pemilu. Sementara mekanisme yang telah diterapkan ini dalam UU No. 2 Tahun. 2008 tentang Partai Politik.

10 Electoral Treshol adalah ketentuan bahwa dalam pemilihan pemilu legislative setiap partai harus meraih minimal3\% jumlah kursi anggota parlemen pusat. Untuk pemilihan Presiden dan Wakil Presiden, Partai Politik harus memperoleh kursi dalam bidang yang bersangkutan sebanyak 3\% atau5\%darisuarasahsecaranasional. Lihat, Miriam Budiardjo, Dasar Dasar limm Politik, (Jakarta: PT Gramedia Pustaka Utama, 2004), hal. 483. 
Parlementary threshold adalah penetapan para calon legislatif (caleg) terpilih untuk duduk diparlemen dengan memperhatikan keefektifan dalam menyederhanakan nomor politik dan untuk megurangi perpecahan diparlemen. Sementara upaya untuk menerapkan sistem parlemetary thresbold di Negara Indonesia bukan suatu sistem yang mudah mungkin dibutuhkan banyak waktu untuk menerapakan sistem tersebut karena sudah pasti salah satunya mesti bertentangan dengan partai-partai politik yang kecil dikarenakan menurut partai politik" yang kecil bahwa yang pasti pasti yang lebih besar mesti mendapatkan suara terbesar ketika dijaksanakan Pemilu kedepan.

Sementara bila dilahat dari mekanisme sistem tersebut adalah sangat efcktif dan realitas, guna menempatkan wakil-wakil partai politik di parlemen yang berdasarkan minimal perolehan kursi melaui aturan main. Tentunya mekanisme yang demikian akan berimplikasi positif terhadap kemampuan anggota partai parlemen yang telah dipilih untuk menjalankan fungsinya sebagai wakil rakyat yang memadai dan maksimal.

Implikasi dari penerapan sistem ET terhadap pemilu 2014 sangat berpengaruh pada suara yang didapati oleh setiap parpol maupun parlok untuk dapat menduduki parlemen. Menurut Urbaningrum, ET sendiri Memiliki dua jenis yang berbeda.Yakni, threshold untuk bias ikut pemilu Berikutnya (electoraltbreshold), dan threshold untukbisamasukdi parlemen (parlementarythreshold). Sedangkan secara lebih spesifik. Erawan mendefenisikan, parlementary threshold adalah hak partai politik di Parlemen yang diukur dari banyaknya jumlah kursi yang diperoleh.

Khusus wilayah Provinsi Aceh yang sistem pemerintahannya diatur dalam UU Nomor 11Tahun 2006 Tentang Pemerintahan Aceh (UUPA), menyebutkan bahwa Aceh mempunyai hak dalam pembentukan partai politik lokal, yang kemudian diatur lebih lanjut dalam Qanun Nomor 3 Tahun 2006 Terıtang Partai Politik Lokal (Parlok). ${ }^{12}$

"Pasal 90 UU PA menyebutkan bahwa untuk dapat mengikuti pemilu berikutnya: a. Parlok harus memperoleh sekurang-kurangnya suara 5\% jumlah kursi DPRA;dan b. sekurangkurangnya memperoleh sekurang-kurangnya $5 \%$ jumlah kursi DPRK yang tersebar di $1 / 2$ jumlah Kabupaten/ Kotadi Acehal.

12 Pasal 34 Qanun No. 3 Tahun 2006. 


\section{E. Pendekatan yang Digunakan}

Salah satu cara yang digunakan dalam suatu pendekatan dalam kebijakan politik dalam menghadapi Pemilu 2014 kedepan adalah dengan cara melakukan sebagai sosialisai dan pendekatan terhadap masyarakat yang tinggal dalam wilayah Aceh, baik itu dengan cara ketika naik keatas mimbar lalu menyampaikan berbagai keinginan ataupun misi kedepan yang ingin dicapai dengan menggunakan media partai politik tertentu.

Ada beberapa tindakan yang dapat dilakukan pemilih dalam pesta demokrasi rakyat lima tahunan tersebut. Pertama, katanya, ijtihad politik menjelang pemungutan suara, kedua usaha amar makruf nahi mungkar dengan menconteng kolom nama atau nomor calon legislatif (caleg) yang memiliki kualifikasi jujur, amanah dan cerdas.Sedangkan yang perlu dihindari adalah bersikap golput, katanya. "Karena jika kita orang-orang yang baik tidak mengikuti pemilihan maka orang-orang yang jahat akan memilih, seharusnya orang-orang bisa terpilih melalui usaha-usaha kita, menjadi tidak terpilih," katanya.

\section{Pendekatan Sosio-Politik}

Fenomena yang terjadi dalam masyarakat yang tinggal di wilayah Kota Lhokseumawe adalah kerap sekali berkecimpung dalam dunia politik baik itu masyarakat awam bahkan ulama sekalipun seperti halnya yang pernah dilakukan yang memahami bahwa jalan politik dan cara ini adalah sebagai kesempatan yang maksimal sehingga dapat mencakup berbagai aspek dan lini.

Akan tetapi munkin bila dilihat dan diamati bahwa ulama sekarang sebagian masyarakat menganggap fungsi ulama seperti yang tersebut di atas, sebagian besar masyarakat menilai ulama sekarang kurang berperan dalam menyelesaikan konflik dengan bermacam alasan. Ada yang sangat negatif dengan mengatakan bahwa ulama sekarang tidak lagi mencari dari ridha Allah dan tidak berani berkata yang benar. Ada juga yang memberi alasan yang 
kondisional misalnya sebagian ulama sudah pudar citranya karena telah diperalat oleh kelompok tertentu baik di masa orde baru mau pun sekarang. ${ }^{13}$

Kendaúpun demikian, rakyat tetap terikat dengan ulama dalam kehidupan sosial keagamaan, seperti terlihat sekarang pada setiap kampung di Aceh terdapat dua pemimpin yaitu keuchik dan imuem. Keucbik adalah pemimpin dunia yang bertanggung jawab terhadap administrasi kampung, sedangkan imuem adalah seorang pemimpin agama yang bertanggung jawab terhadap pelayanan agama. Keuchik dan imuem dalam masyarakat Aceh diibaratkan sebagai ayah dan ibu bagi masyarakat. Keuchik, tidak dapat memutuskan suatu keputusan yang menyangkut dengan sosial keagamaan secara sendirian tapi mesti atas dasar restu imuem meunasab atau diistilahkan dengan teungku sagou.

Ulama berperan memben nasihat pada pemerintah di setiap jenjang pemerintahan mulai dari tingkat desa dan seterusnya ke atas, seperti di kecamatan, kabupaten, dan provinsi. Dengan berdirinya MPU yang sebelumnya dikenal dengan Majlis Ulama Indonesia (MUI) sebagai penasihat pemerintah tentang persoalan agama, ulama mendapat legitimasi untuk memberi masukan bagi pemerintah. Lembaga keulamaan ini didinkan pertama kali di Aceh pada tahun 1965 dan kemudian menjadi model bagi pemerintah pusat Indonesia dan provinsi lainnya. ${ }^{14}$

Ulama sebagai satu titik rasionalisasi penerus risalah suci kenabian dituntut independen dari berbagai pragmatisme kepentingan sosial temporer. Misalkan kepentingan politik praksis dan kepentingan-kepentingan sempitsektarian lainnya. Keberpihakan dan keterlibatan ulama dalam "huru-hara" politik praksis akan memberi peluang terjadinya reduksi serta distorsi atas nilainilai dan spirit ke-ulamaannya sebagaimana telah disebutkan di muka.

Banyak ulama yang terlibat dalam politik praksis kehilangan legitimasi personal dan legitimasi sosial di mata umat. Akibat "bermain-main" dan tercemar oleh bias politik yang mengitarinya. Meskipun demikian banyak pula ulama kendati terjun dalam "huru-hara" politik praksis tetap memiliki jarak,

13 Hasbi Amiruddin. Perjuangan Ulama Aceh di Tengah Konflik, (Yogyakarta: Ceninnets Press, t.t.), hal. 92.

14 M. Hasbi. Ulama Dayah, hal. 29 dan Lihat juga. Ulama dan Politike. hal. 52. 
memiliki legitimasi personal dan sosial karena kemampuannya menempatkan nilai-nilai ilmiah kesarjanaan dan kecendekiawanannya dalam rule politik praksis. Ulama sebagai pilar sosial idealnya berada dan menempatkan posisi dalam katup sosial yang lebih luas, netral dan independen. Tidak terjebak dalam katup-katup sosial yang sempit, misalkan keterlibatan ulama dalam katup politik praksis.

Interaksi sosial ulama dan umat yang konstruktif dapat saja mengalami pergeseran dan terganggu karena hal tersebut. Sebagaimana menurut Pasal 4 ayat 1 UU No. 44/1999 tentang Penyelenggaraan Keistimewaan Aceh "Penyelenggaraan kehidupan beragama di daerah diwujudkan dalam bentuk pelaksanaan Syari'at Islam bagi pemeluknya dalam masyarakat". Perda No. 5/2000 tentang Pelaksanaan Syari'at Islam telah mengatur secara rinci pelaksanaan syari'at secara kaffah, mencakup aspek aqidah, ibadah, muamalat, akhlak, pendidikan dan dakwah islamiah/amar makruf nahi mungkar, baitulmal, kemasyarakatan, syiar Islam, pembelaan Islam, qhada, jinayat, munakahat dan mawaris. ${ }^{15}$

\section{Pendekatan Sosio-Masyarakat yang Digunakan}

Tugas utama ulama menurut versi ulama sendiri adalah mendidik masyarakat dalam bidang agama atau sesuatu kepada mengenai Allah, melaksanakan segala perintahnya, perintah rasulnya dan mampu menjalankan ibadah-ibadah serta berakhlak mulia. Tugas selanjutnya adalah dakwah dalam arti mendakwahkan agama kepada masyarakat luas di mana saja berada baik diundang ataupun tidak. Beda antara mendidik dan mendakwah adalah mendidik dalarn arti peserta pengajian khusus. ${ }^{16}$

Sebenarnya ada peranan lain yang dimainkan oleh ulama-ulama di Aceh yang kurang terpantau oleh masyarakat umum yaitu kegiatannya pada tingkatan bigh politik. Ulama ini sering memberi arah kebijakan pemerintah secara tidak langsung, karena mereka sering membuat approach secata pribadi karena

15 Badruzzaman. Bagaimana keterlibatan ulama dalam gerakan politik di Aceh, 2003, hal. 12.

16 Hasbi Amiruddhin, Pejuangan Ulama Aceb di Tengab Konflik, (Jakarta: Geninnets Riress, 2004), hal. 97. 
kemampuannya dalam membuat pendekatan-pendekatan kepada pihak-pihak tertentu yang dianggap signifikan dalam menentukan arah negara ini. Akrivitas ini tidak dapat dilakukan oleh semua ulama hanya ukma-ulama tertentu saja mampu melakukannya. Mereka biasanya memiliki kharisma lebih dan yang lain dar kemudian memiliki diplomasi yang tinggi dalam memberi pemikiranpemikiran kepada pihak yang dianggap signifikan.

Aktivitas ulama sebagai pimpinan dayah/pengajian, pendakwah atau pemberi nasihat di dalam masyarakat ulama telah berfungsi sebagai pengawal agama dan pengayom masyarakat dari krisis agama dan krisis akhlak. Kalaupun mereka aktif di organisasi baik itu ormas maupun di parpol mereka juga selalu konsen dengan agama masyarakatnya. Mereka selalu menjadi benteng atau rem dari ketersesatan umat baik yang mengarah ke arah musyrik atau ke pekerjaan fasiq dan maksiat. ${ }^{17}$

\section{F. Karakter Ulama Berpolitik}

"Ulama Politik" sama dengan ulama su'. Kata su' adalah mashdar dari sa'a artinya jelek, buruk atau jahat. Dengan demikian secara etimologi "ulama su" (ulama politik) adalah ahli ilmu yang jahat clan buruk. Sedangkan secara terminology adalah orang yang menggunakan ilmunya untuk menyimpang dari aturan Allah dan memanfaatkan ilmunya untuk kepentingan pribadi atau kelompoknya saja. Paling tidak karakter "ulama politik" itu, antara lain:

Pertama, Beramal tidak sesuai dengan ilmunya, tetapi mengikuti hawa nafsunya.

Kedua, ulama yang hanya menjadi stempel penguasa (salathin). Menurut az-Zahabi, ulama s' adalah ulama yang mempercantik kezaliman dan ketidakadilan yang dilakukan oleh penguasa. Ulama yang memutarbalikkan kebathilan menjadi kebenaran untuk penguasa atau ulama yang diam saja di hadapan penguasa padahal ia mampu menjelaskan kebenaran.

Ketiga, tamak terhadap dunia. Artinya, ulama yang dengan ilmunya bertujuan mencari kenikmatan dunia, meraih gengsi dan kedudukan. Umar bertanya kcpada Ka'ab: "apa yang megeluarkan ilmu dari hati ulama?" Ka'ab 
menjawab: "Ketamakan". Keluarnya ilmu dari hati artinya ilmu itu sudah tidak berpengaruh dan tidak lagi dijadikan tuntunan.

Keempat, sombong dengan ilmunya. Kata "tidak tahu" tidak ada dalam kosa kata ulama su'. Ia merasa gengsi mengatakan tidak tahu. Padahal orang sekaliber Ibnu Umar saja tidak merasa malu untuk mengatakan tidak tahu. Ibnu al-Mubarak meriwayatkan dari lbnu Umar, bahwa ia pernah ditanya tentang sesuatu, lalu ia menjawab, "Aku tidak tahu".

Kelima, mereka mengatakan apa yang tidak mereka lakukan. "Politik Ulama" adalah ulama yang sebenarnya. Ulama yang benar adalah yang berkarakter sebaliknya dari karakter ulama su', antara lain: pertama, beramal sesuai dengan ilmunya. Kedua, ulama yang sebenamya adalah ulama yang berani mengatakan kebenaran di hadapan penguasa dan menegakkan keadilan di hadapan penguasa yang zalim. Ulama bukan stempelnya penguasa tetapi yang meluruskan dan mengarahkan penguasa agar selalu berada di jalan yang benar. Bahkan Rasul bersabda: "Seutama-utama jihad adalah menegakkan kebenaran pada penguasa yang zalim". Sa'di bercerita bahwa alkisah, seorang raja yang zalim berkenan memanggil seorang ulama ke istananya untuk memberi nasihat. Ketika ulama itu datang, raja berkata: "Berikan aku nasihat. Amal apa yang paling utama aku lakukan sebagai bekalku kelak di akhirat?”. Sang ulama menjawab: "amal terbaik untuk baginda adalah tidur". Raja itu keheranan, "mengapa?", karena ketika tidur, jawab ulama itu, Ketika raja tidur, rakyat dapat beristrahat dari kezaliman." Sekelumit kisah tentang keberanian ulama untuk menyampaikan kebenaran di hadapan penguasa yang zalim. Ketiga, tidak tamak terhadap kehidupan dunia. Keempat, tidak sombong dengan ilmu yang dimilikinya. Kelima, sesuai antara perkataan dan perbuatan. Karakter seperti inilah yang disebut "politik ulama" yang dapat memainkan perannya dalam membangun bangsa. Paling tidak tanggung jawab ulama ke depan dapat dioptimalkan. Ada beberapa tanggung jawab ulama, antara lain: pertama, tanggung jawab keagamaan (mas'uliyyah diniyyah). Kedua, tanggung jawab keumatan (mas'uliyyah ummatiyab) yang meliputi kebutuhan primer (dharuriyah), sekunder (bajiyyab) dan tertier (tabsiniyyah/takmiliyyah). Ketiga, tanggung jawab 
yang berkenaan dengan kehidupan berbangsa dan bernegara (mas'uliyyah wathaniyyab).

\section{G. Penutup}

Dari hasil penelitian yang telah dilaksanakan di lapangan menunjukan bahwa di Nanggroe Aceh Darussalam (NAD) peran dan sikap ulama sangat dominan yang selalu dijadikan sebagai bahan rujukan dari berbagai aspek kehidupan, baik aspek sosial, ekonomi, budaya dan tentunya dalam mentransformasi politik adalah sebagai media untuk mensinergikan dari segala bidang agar kiranya jika ulama terlibat langsung dalam mengambil suatu kebijakan ataupun statemen kepada pablik dapat tersentuh dan mengetahui permasalahan yang sebenarnya dalam masyarakat pada umumnya. Hingga saat ini, ulama telah mengambil dan memberikan warna tersendiri dalam kancah pcrpolitikan di Aceh, baik itu yang bergabung dengan partai nasional (Parnas) ataupun bergabung dengan partai lokal (Parlok) dan tentunya antara satu partai dengan partai yang lain berbeda visi dan misi, baik itu secara program kerja bahkan berbeda ideologi sekalipun dan ini sudah menjadi rahasia publik. Jika menghadapi pesta demokrasi dalam pemilihan kepala daerah tidak jarang terdapat antara satu partai dengan partai lainnya terdapat perang syaraf dan sehingga menimbulkan kearah perspektif yang negatif dan sudah pasti hal ini sangat merugikan masyarakat setempat dan ini adalah kenyataan yang sebenarnya didapati di Aceh. Wallabu A'lam.

\section{DAFTAR PUSTAKA}

Amiruddin, Hasbi. 2004. Perjuangan Ulama Aceb di Tengah Konflik. Yogyakarta: Ceninnets Press.

Badruzzaman. 2003. Bagaimana Keterlibatan Ulama dalam Gerakan Politik di Aceh. Banda Aceh: Majelis Pendidikan Daerah Aceh.

Bahan-bahan Seminar.1978. Sejarah Masuk dan Berkembangnya Islam di NAD. Banda Aceh: Majlis Ulama Indonesia (MUI-NAD). 
Bakker, Anton. 1990. Metodologi Penelition Filsafat. Cet. I. Yogyakarta: Kanisius.

Budiardjo, Miriam. 2004. Dasar Dasar Ilmu Politik. Jakarta: PT Gramedia Pustaka Utama.

Daerah Istimewa Aceh, 1992. Buku Profil Provinsi Republik Indonesia. Jakarta: Yayasan Bhakti Wawasan Nusantara.

Hasbi M, 2003. Ulama Dayah, Lhokseumawe: Nadiya Foundation. Cet. 1.

Ibrahim, Fairus M. Nur (ed), 2002, Syari'at di Wilayah Syari'at: Pernik-Pernik. Islam di Nanggrae Aceh Darussalam.Banda Aceh: Dinas Syari'at Islam.

Ismuha, 1983. Sejarab Singkat Ulama Provinsi Daerah Istimewa Aceh. Banda Acch:

Sekretariat MUI Provinsi D.I. Aceh.

Laporan. 1972. Monografi Daerah Istimewa Aceh. Banda Aceh: Universitas Syiah Kuala Darussalam,

Narbuko Kholid. 2002. Metodologi Penelitian. Jakartã: Bumi Aksara.

Rais, Amien. 1987. Cakrawala Islam Antara Cita dan Fakta. Jakarta: Mizan Pustaka.

Sufi, Rusdi, (peny). 2004. Adat Istiadat Masyarakat Aceh, Banda Aceh: Balai Kajian Sejarah dan Nilai Tradisional Banda Aceh.

Subqi, Badruddin. 1995. Dilema Ulama Dalam Perubahan Zaman. Jakarta: Gema Insani Press.

Talsya T. Alibasya. 1985. Adat Resam Aceh. Banda Aceh: Pustaka Mutia.

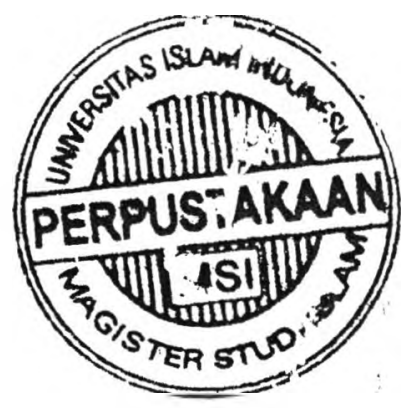

